\title{
SOME PERTURBED INEQUALITIES OF OSTROWSKI TYPE FOR TWICE DIFFERENTIABLE FUNCTIONS
}

\author{
SAMET ERDEN, HÜSEYIN BUDAK, and MEHMET ZEKI SARIKAYA
}

\begin{abstract}
We establish new perturbed Ostrowski type inequalities for functions whose second derivatives are of bounded variation. In addition, we obtain some integral inequalities for absolutely continuous mappings. Finally, some inequalities related to Lipschitzian derivatives are given.
\end{abstract}

MSC 2010. 26D15, 26A45, 26D10.

Key words. Function of bounded variation, perturbed Ostrowski type inequalities.

\section{REFERENCES}

[1] M.W. Alomari, A generalization of weighted companion of Ostrowski integral inequality for mappings of bounded variation, Research Group in Mathematical Inequalities and Applications, 2011, Article 87, 1-11.

[2] M.W. Alomari, Generalization of Dragomir's generalization of Ostrowski integral inequality and applications in numerical integration, Ukrainian Math. J., 64 (2012), 435450.

[3] H. Budak and M.Z. Sarıkaya, On generalization of Dragomir's inequalities, Turkish Journal of Analysis and Number Theory, 5 (2017), 191-196.

[4] H. Budak and M.Z. Sarikaya, A new generalization of Ostrowski type inequality for mappings of bounded variation, Lobachevskii J. Math., 39 (2018), 1320-1326.

[5] H. Budak and M.Z. Sarikaya, A new Ostrowski type inequality for functions whose first derivatives are of bounded variation, Moroccan Journal of Pure and Applied Analysis, 2 (2016), 1-11.

[6] H. Budak, M.Z. Sarikaya and S.S. Dragomir, Some perturbed Ostrowski type inequality for twice differentiable functions, in Advances in Mathematical Inequalities and Applications, Trends in Mathematics, Birkhäuser, Singapore, 2018, 279-294.

[7] H. Budak and M.Z. Sarikaya, Some perturbed Ostrowski type inequality for functions whose first derivatives are of bounded variation, International Journal of Analysis and Applications, 11 (2016), 146-156.

[8] S.S. Dragomir, The Ostrowski integral inequality for mappings of bounded variation, Bull. Aust. Math. Soc., 60 (1999), 495-508.

[9] S.S. Dragomir, On the Ostrowski's integral inequality for mappings with bounded variation and applications, Math. Inequal. Appl., 4 (2001), 59-66.

[10] S.S. Dragomir, Approximating real functions which possess nth derivatives of bounded variation and applications, Comput. Math. Appl., 56 (2008), 2268-2278.

The authors thank the referee for his helpful comments and suggestions.

DOI: $10.24193 /$ mathcluj.2021.2.09 
[11] S.S. Dragomir, Some perturbed Ostrowski type inequalities for functions of bounded variation, Asian-Eur. J. Math., 8 (2015), 1-14.

[12] S.S. Dragomir, Some perturbed Ostrowski type inequalities for absolutely continuous functions (I), Acta Univ. M. Belii Ser. Math., 23 (2015), 71-86.

[13] S.S. Dragomir, Some perturbed Ostrowski type inequalities for absolutely continuous functions (II), Acta Univ. Apulensis Math. Inform., 43 (2015), 209-228.

[14] S.S. Dragomir and N.S. Barnett, An Ostrowski type inequality for mappings whose second derivatives are bounded and applications, J. Indian Math. Soc. (N.S.), 66 (1999), $137-245$

[15] S.S. Dragomir, and A. Sofo, An integral inequality for twice differentiable mappings and application, Tamkang J. Math., 31 (2000), 257-266.

[16] W. Liu and Y. Sun, A Refinement of the Companion of Ostrowski inequality for functions of bounded variation and Applications, arXiv:1207.3861, 2012, 1-10.

[17] Z. Liu, Some Ostrowski type inequalities, Mathematical and Computer Modelling, 48 (2008), 949-960.

[18] A.M. Ostrowski, Über die absolutabweichung einer differentiebaren funktion von ihrem integralmitelwert, Comment. Math. Helv., 10 (1938), 226-227.

[19] A. Rafiq, N.A. Mir and F. Zafar, A generalized Ostrowski-Grüss Type inequality for twice differentiable mappings and application, Journal of Inequalities in Pure and Applied Mathematics, 7 (2006), Article 124, 1-7.

[20] M.Z. Sarikaya and E. Set, On new Ostrowski type Integral inequalities, Thai J. Math., 12 (2014), 145-154.

[21] M.Z. Sarikaya, H. Budak, T. Tunc, S. Erden and H. Yaldiz, Perturbed companion of Ostrowski type inequality for twice differentiable functions, Facta Univ. Ser. Math. Inform., 31 (2016), 595-608.

Received November 19, 2019

Accepted May 28, 2020

\author{
Bartın University \\ Department of Mathematics \\ Bartın, Turkey \\ E-mail: erdensmt@gmail.com \\ https://orcid.org/0000-0001-8430-7533 \\ Düzce University \\ Department of Mathematics \\ Düzce, Turkey \\ E-mail: hsyn.budak@gmail.com \\ https://orcid.org/0000-0001-8843-955X \\ E-mail: sarikayamz@gmail.com \\ https://orcid.org/0000-0002-6165-9242
}

